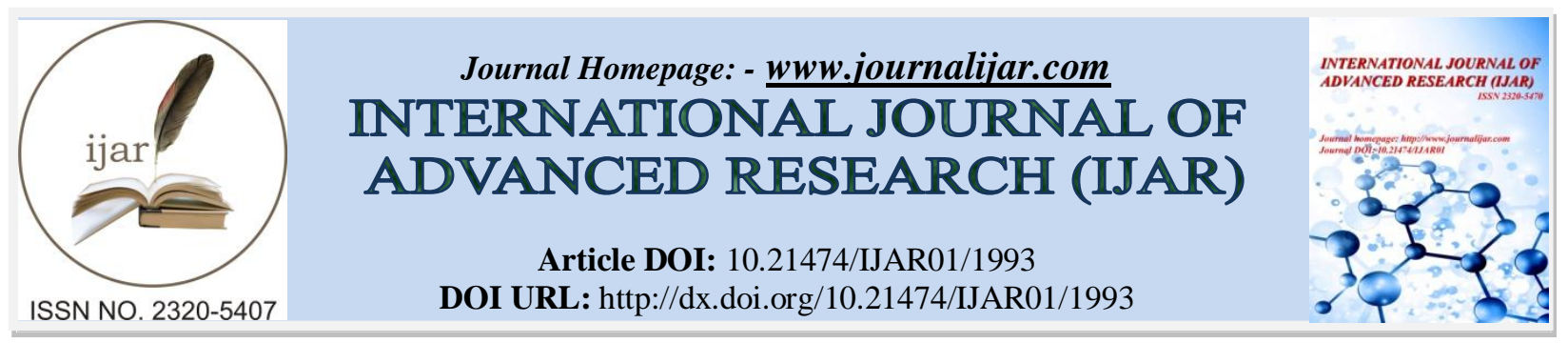

RESEARCH ARTICLE

\title{
CHALLENGES AND STRATEGIES OF RURAL DEVELOPMENT IN ASSAM.
}

Monjita Basumatary.

Gogamukh (Dhemaji), Assam, India.

\section{Manuscript Info}

Manuscript History

Received: 15 September 2016

Final Accepted: 25 October 2016

Published: October 2016

Key words:-

Agriculture, Aiming, Chronic,

Implemented, Scarcity Strategy.

\section{Abstract}

Assam is situated in the middle of the North Eastern Region. About $80 \%$ people are in rural area. People are mainly depend on agriculture, But chronic flood and using of low level of technology led poor production of Agriculture and other allied activities further led rural people scarcity of food, cloth and shelter, which effect in economic, social education and health of the rural area. Now the central and state Government has jointly implemented various plans and programmes aiming Rural Development. Minimum needs programme, NREGA, EGS etc. are notable. Now this paper attempt to study the challenges and strategies of Rural Development in Assam as well as to find out the way of Rural Development.

Copy Right, IJAR, 2016,. All rights reserved.

\section{Introduction:-}

There is no universal accepted meaning about Rural Development. It is comprehensive and Multi-dimensional and Multi context. The World Bank 1975 defined Rural Development as "A strategy aiming at the improvement of Economic and social living conditions focusing a specific group of poor people in rural area. It assist the poorest groups. According to Robbert Chambers Rural Development is a strategy to enable a specific group of poor people, women and men to gain economic benefit and social development. Thus Rural Development study encompasses the education, health, agriculture, forest, tourism, employment, eradication of poverty etc.

Assam is situated in the middle of the North East. About $80 \%$ people are in rural area. Agriculture is their main livelihood. Industry, market, communication, health etc. are all relation with Agriculture. As Assam is chronic flood affected area and far from central Government Administration, most, rural area of Assam remain unpaid attention. Besides, as agriculture is the main livelihood of the people of rural areas, low income, unemployment, scarcity of food, fodder lack of irrigation etc. are mainly due to low level of agriculture in rural area. Health and education problem can be solved when rural areas improved in livelihood, Contd..............p/2 (2) e.g.- agriculture. Low level of livelihood effect in every field of rural area in socio-economic, political, religion, education etc. Now the Assam Government in collaboration with Central Government has jointly implemented various policies and programmes aiming rural development. Minimum needs programme (1973). Integrated Rural Development Programme (IRDP, 1778), National Rural Employment Programme (NREP,1980), Training for Rural Youth for Self-Employment (TRYSEM, 1979), National Rural Employment Guarantee Act (NREGA,2005) etc. are notable among them. But these plan and programme are not yet fully reached and implemental for various reasons of illiteracy, ignorant, lack of confidence, structural defects of plan and programmes etc. 


\section{Concept of Challenge:-}

In the way of development activities in rural areas some factors stand hindrance which are challenges of rural development. These are:- poverty, unemployment, lack of confidence and skill, illiteracy, ill health etc.

\section{Strategy:-}

Strategy is device of Rural Development. So, rural Development strategy mean possible situation of development in rural areas. It is directive to fulfill the objectives of Rural Development. It is concerned with Industry, Agriculture, Socio-economic Development of Rural people prepared by experts jointly with Central Government and state Government.

\section{Rural Area:-}

Rural areas are thinly populated places away from the influenced of large cities and towns. Such areas are distinct from intensively settled urban and suburban areas and are depended on agriculture. Access of Government Services, Hospital, Educational institutions, Drinking Water Facilities, Street Lighting and electricity are limited.

\section{Development:-}

Development refers to the growth and development and progress in a gradual and sequential manner. It also refers to the overall movement of growth towards greater efficiency in socio-economic, education, administration, industry etc.

\section{Rural Development:-}

Rural Development is a process which aims of improving the well being and self realization of people living in rural areas through collective process. According to Agrawal(1989). Rural Development is a strategy designed to improve the economic and social life of rural poor. The United Nations defines Rural Development as bringing change among rural community from the traditional way of living to progressive way of living.

Contd.......p3

(3)

\section{Objective of the study:-}

1. To study the challenges and strategies of Rural Development.

2. To find out the way of Rural Development.

3. To aims at improving the quality of people in rural areas in socio-economic, physical, technological and infrastructural fields.

\section{Importance:-}

Rural areas is backbone of urban development. From agriculture to natural resources everything is available in rural areas. It needs proper utilization and manipulation to growth and development. But various challenges stand hamper in the way of growth and development in rural area, which needs detail study to point to out.

\section{Methodology:-}

The paper is prepared by taking recourse to the descriptive, analytical and conceptual methods. Further the paper is briefly describe the challenges and strategy of rural development in Assam. In writing this paper data is collected from secondary sources of books, news papers, magazine \& journal etc.

\section{Review of Literature:-}

Accordingly to Mishra and Sharma (1979) rural development is not merely development of rural areas but also the development of quality of life of the rural masses into self -reliant and self sustaining modern communities, so that each rural people changes in a desired direction.

The Ashridge Conference as Social Development emphasized that Rural Development should be designed to promote better living for all in the whole community with the active participation and initiative of the community.

Singh (1986) pointed out that development is not only an increase in income and infrastructural facilities but it also brings about changes in the attitude of the people. Development is not- only implementing Government package programmes but it means to develop and to obtain desirable change of the rural people. 
Goulet (1971) finds that developments starts from within the social system and touches the individual towards some conditions regarded as humanly better.

Kothari (1991) said that development programme had only touched the surface and so called for a micro-planning approach to find out solution to the multi-dimensional problems of rural India.

Contd.............p/4

(4)

Moheswari(1985) holds the view that rural areas have their own natural resources and science could suggest ways and means of exploiting them with a view to giving additional and fuller employment to the local population.

Singh (1998) classified resources into three main categories (i) Natural resources (ii) human resources (iii) land. He further recommended the importance for balanced utilization of local resources.

Singh(1986) states that if the human resources of a country are not properly developed by proper nutrition, health care, education and training and are not productively utilized these resources become a liability and an obstacle to development.

\section{Interpretations:-}

The people in rural areas of Assam are mainly depended on agriculture $80 \%$ people are agriculturists. But due to traditional methods of cultivation, production is very low. Farmers are far from using high technology in production methods. Floods and other natural calamities like pests damaged half percent of agriculture. In 1986 environment protection law was formed. For environment protection both Government and public has working together in implementing plan and programme smoothly.

Unemployment, illiteracy and poverty are also serious problems of rural areas in Assam. Now Government of India as well as Assam Government has jointly implemented new schemes and policies to abolish these problems. MidDay-Meal scheme, IAY, SGRY, National Maternity benefit scheme etc. are among them. Besides prevailing sociocultural factors of family also influenced the rural people, mainly nuclear or joint family is prevalent in Assam, which influenced every society in rural area in socio-economic condition. Laziness, drudgery are other problems that needs to be tackle. To achieve this purpose human resources management facilities should be provided for the growth and development of their inner potentialities. Also Assam is very rich in diversity of natural resources. But due to lack of technological knowledge and skill these resources are yet to be utilized in developmental purpose.

\section{Findings:-}

1. Study shows that Agriculture is the main livelihood of the rural people of Assam.

2. Flood is the chronic problems of rural area in Assam.

3. Illiteracy, unemployment and poverty are remarkable problems in the rural development of Assam. Condt.................p/5 (5)

4. Some problems connected with joint and nuclear family, other socio-cultural and traditional customs stand in the way of rural development. Study shows that these can be tackle by implementing human resources management project.

5. NREGA, SHG, IRDP etc. has done a lot for the qualitative and quantitative development of the rural people.

6. Abundant natural resources of Assam is not yet properly able to utilized for lacking scientific and technological knowhow.

\section{Way of rural Development:-}

1. Mainly, livelihood, health and education are the main problem of Rural area. Scarcity of food, fodder, fuel, poor crops yield, lack of irrigation etc. are livelihood problems. These are serious problems of rural area and need to be tackle immediately. The health and education problem can be solved easily if livelihood problems is tackle immediately.

2. Good moral values and commitment for upliftment of the community are also essential for rural development.

3. The rural poor people should be motivated to handle efficiently the inputs and finances for rural development instead of sympathy, so that finances supplied for developmental purpose are not diverted for household consumption. 
4. The rural development programme should facilitate sustainable management of natural resources and environment protection.

5. Resources are limited with connection to human wants. So, it should be use properly and preserved for future utilization.

6. Various organization NGO, SHG should be organized based on rural communities to implement the plans and project initiated by Government.

7. Women, children, age old and weaker sections of Rural People should be given top priority.

8. Educational institutions should be established and trained teacher should be provided in rural area.

\section{Conclusion:-}

The Government has launched various plans an programmes for rural development in Assam. IAY, NREP, SGRY, IRDP etc. are provided considerably. Achievement of these programmes are seen in every field of shelter, employment, economic development \& industry of the rural areas. But due to excessive dependent on Government and structural defects of policy and programme launched, accepted targets of achievement has not reached in the far flung rural areas in Assam. For all round comprehensive development rural people should have to shoulder risk for their development. So, dimension of psychological development of rural people as well as practical effort is most important, otherwise rural development in Assam is impossible.

Contd.........p/6 (6)

\section{References:-}

1. An Administration of Rural Development in India, Dr. Namita Dutta Baruah.

2. Rural Development Principals and Policies and Management - Katar Singh.

3. 3. Rural Development in India- Vasant Desai.

4. Rural Development Policies and Programmes. Sage Publication, New Delhi- 1984- Mehata S.R. 